\title{
Canadian Insights into NATO Maritime Strategy, 1949-70: The Role of National and Service Interests 1
}

\section{Isabel Campbell}

Cet article examine la stratégie maritime d'OTAN en abordant les intérêts nationaux, la rivalité entre les services, et l'impact des objectifs des forces sur la planification navale pendant le début de la Guerre Froide. Il souligne les efforts de la Marine Royale du Canada pour premièrement influencer les mesures américaines et ensuite les mesures de l'alliance pour contrer la nouvelle menace des sous-marines lancemissiles du milieu à la fin des années 1950s. Malgré le fait que les intérêts nord américaines et européennes ont divergé et que les ressources ont décalées, les forces maritimes canadiennes ont continué à jouer un rôle diplomatique dans la rassurance des européens d'un engagement nord américain envers leur défense.

The North Atlantic Treaty Organization (NATO), created in April 1949 by Belgium, Canada, Denmark, France, Iceland, Italy, Luxembourg, the Netherlands, Norway, Portugal, the United Kingdom and the United States, provided the smaller allies with formal input into strategic decisions which they had been denied during the Second World War. ${ }^{2}$ At

\footnotetext{
1 The author thanks Roger Sarty, Matthew Trudgen, Michael Whitby, and Steve Harris for useful comments on this paper which was based upon research performed for the preparation of volume three of the official history of the Royal Canadian Navy. However, it does not represent the views of the Department of National Defence and the author takes responsibility for all errors.

${ }_{2}$ In September 1949 the North Atlantic Council, composed of all the NATO foreign ministers, established a Defence Committee made up of all NATO defence ministers, a Military Committee of all NATO Chiefs of Staff (MC), a Standing Group (SG) that included Britain, France, and the United States, and five regional planning groups. Directorate of History and Heritage, National Defence Headquarters, Ottawa, (DHH), Raymont fonds, 73/1223, box 60, Special meeting, Strategic guidance - NAORPG, SG 13, 7 December 1949. While the SG produced strategic
} 
times, the services of one or another of these countries created innovative plans outside the NATO forum and then tried to affect alliance strategy, command structures, and resource allocations. ${ }^{3}$ This paper touches upon national interests, inter-service rivalry, and the impact of force goals on naval plans, particularly highlighting the Royal Canadian Navy's successful efforts to influence first American and then Alliance measures to counter the new threat of missile-firing submarines during the mid-tolate $1950 \mathrm{~s}^{4}$ It demonstrates that studies of NATO's maritime strategy must consider the inter-play of national, bilateral, trilateral and multilateral defence plans. Such multi-faceted research is particularly challenging because not all of the relevant alliance and national documents have been declassified. ${ }^{5}$ However, an analysis of the open sources about selected major NATO exercises and changes in command structure bearing on Canada's maritime forces reveals two major themes.

First, the leaders of Canada's maritime forces thought independently about the nation's defence. They worked closely with the Americans, but also conferred with other NATO partners about the revision of strategy and plans, the distribution of resources to protect Canada's coasts (the longest of any nation's with uncharted Arctic islands and waters), and changes in the allied command structure. ${ }^{6}$ Canada preferred a multilateral approach, working with the North Atlantic Ocean Region Planning Group (NAORPG) and the Americanled command, the Supreme Allied Commander Atlantic (SACLANT) which replaced NAORPG in 1952. While for security reasons, the

guidance, the other bodies commented upon it and approved it. Douglas Bland, The Military Committee of the North Atlantic Alliance. A study of Structure and Strategy (New York, 1991), and Robert S. Jordon, The NATO International Staff/Secretariat 1952-1957 (London, 1967). C.P. Stacey, Arms, Men, and Governments: The War Policies of Canada 1939-1945 (Ottawa, 1970).

${ }^{3}$ For example, the American chief of naval operations, Admiral Louis Denfield pushed to hold the Soviets back as far east as possible in Europe in part to counter inter-service battles with the United States Air Force. See Joel J. Sokolosky, Seapower in the Nuclear Age. The United States Navy and NATO, 1949-1980 (Annapolis, MD, 1991), 15.

4 Isabel Campbell, "A Transformation in Thinking. The RCN's Naval Warfare Study Group of 1956" in People, Policy and Programmes. Proceedings of the $7^{\text {th }}$ Maritime Command Historical Conference (2005), Richard H. Gimblett and Richard Mayne (eds) (Ottawa, 2008) The present article builds upon this earlier work.

5 In the present article, I have relied upon releases from Admiralty records which contain criticisms of American performances. Open American and Canadian records are largely still limited to public relations releases and therefore not helpful in balancing these assessments.

${ }^{6}$ Canada's mainland coastline, including Newfoundland and Prince Edward Island, but excluding other islands, measures over 58,000 km. The argument and evidence here supports Nicholas Tracy's contention that participation in such collective defence allowed Canada to limit its subordination to other countries. Nicholas Tracy, The Two-Edged Sword. The Navy as an instrument of Canadian Foreign Policy (Kingston and Montreal, 2012). 
Americans did not share Canada-US continental defence plans with European allies, the Canadians regarded North American security as a vital element in NATO strategy and insisted upon counting Canadian contributions to coastal defence towards NATO force goals. ${ }^{7}$ Second, Canada's naval chiefs used alliance politics to promote new resources like the St. Laurent destroyers and Oberon submarines. NATO maritime strategy favoured an appearance of preparedness and solidarity over actual readiness for battle and so the navy's leaders were also able to use the alliance to protect older refitted warships, like the carriers, cruisers, and frigates, although the latter had increasingly limited capabilities for tasks assigned to them. The need for alliance solidarity in the face of competing national and service interests took attention away from an accurate assessment of Soviet intentions and capabilities and, hence, from a focus on fewer, better resources. Rather, NATO's maritime strategy stressed deterrence with a larger numbers of warships at the cost of efficiency and high performance. In the case of the Royal Canadian Navy (RCN), supporting these numbers stretched naval personnel very thin.

Despite Stalin's aspirations for a blue water fleet, the Soviet Union faced significant economic constraints and the Soviet navy lagged behind its American counterpart. ${ }^{8}$ In the early post war period, the lack of a significant Soviet maritime threat, the American air force's monopoly in nuclear weapons, and pressure for demobilization made it impossible for the United States Navy (USN) to achieve its ambitious plans for a new generation of major warships. ${ }^{9}$ Although American-Canadian continental defence plans tasked the USN and RCN with the protection of the sea and air lines of communication, maritime defence was not a high priority in either country. ${ }^{10}$ In December 1946, Lester B. Pearson,

\footnotetext{
7 DHH, 2002/17, box 23, file 138, folder 1 of 4, Annual Review, 1953, ARQ (53), draft country chapter on Canada, 22 October 1953. In the early years, CUSRPG included coastal defence of the Atlantic and Pacific coasts. The United States sanitized continental plans, removing detailed force goals before sharing them with other NATO countries and regarded North American defence as an exclusively national and bilateral matter.

${ }^{8}$ Natalia I. Yegorova, "Stalin's Conception of Maritime Power. Revelations from the Russian Archives" in The Journal of Strategic Studies, 28:2 (April 2005), 157-186. Mikhail Monakov and Jurgen Rohwer. Stalin's Ocean-going Fleet: Soviet Naval Strategy and Shipbuilding Programs, 1935-53 (New York, 2013). See also David F. Winkler, Cold War at Sea. High-Seas Confrontation between the United States and the Soviet Union (Washington, 2000).

9 Jakub J. Grygiel, "The Dilemmas of US Maritime Supremacy in the Early Cold War" in The Journal of Strategic Studies, 28:2 (April 2005), 187-216.

10 Library and Archives Canada (LAC), RG 24, 1983-1984/167, box 218, file 11400-ABC22, Joint Canadian-United States Basic Security Plan, Agreed Joint Draft, 5 June 1946. Both navies were to protect overseas shipping in the northern portions of the Western Atlantic and Pacific
} 
the Canadian under-secretary of state for external affairs drew upon American confidences, declaring that "global strategy would be to fight a future war away from North America". ${ }^{11}$ Yet such a war, requiring larger naval forces than the one light fleet carrier, one cruiser, three destroyers, one frigate, and four minesweepers then in service in the RCN, ${ }^{12}$ seemed avoidable, especially in light of the American nuclear monopoly. Canadian naval and military resources would be much larger than before the Second World War, but not large enough to fight a future war. Rather the emphasis was on deterrence and building a cadre of well-trained professional forces that could organize mobilization more rapidly than had been achieved in the two world wars.

The Royal Canadian Air Force (RCAF), responsible for air defence and shore-based maritime aviation, took the lion's share of the modest defence budget. ${ }^{13}$ Patrols by shore based aircraft were cheaper than the substantial naval forces needed to maintain a presence in the vast expanse of Canadian coastal waters. The RCN justified its plans for two light fleet carriers by the need for defence of air and sea lines of communication outside of coastal waters - beyond the range of shore based aircraft - admitting that two carriers required the commitment of fully twenty percent of the 10,000 personnel set by the government as the ceiling for the service. However, by 1947 the RCN could only recruit and retain about 7500 trained regular force members - making any thought of operating a second carrier unrealistic. Reliance upon a single carrier (absent for periodic refits thus denying naval air pilots regular practice) was a weak option, but it was the smallest investment that allowed the $\mathrm{RCN}$ to develop its air arm. The remaining surface warships of the fleet were stretched very thin and were insufficient to provide high speed

areas; to defend Newfoundland and protect sea communications within the coastal areas along with other tasks.

11 United Kingdom, The National Archives (TNA), Cabinet Records, CAB 1313, Cabinet Defence Committee, DO 46, No. 146, December 1946. Report on discussions with Pearson. See also, Memorandum from Under-Secretary of State for External Affair to Prime Minister, 26 December 1946, Donald Page (ed.), Documents on Canadian External Affairs, 1946, 12, 999 (online edition).

12 The RCN fleet included the light fleet carrier, Warrior, the cruiser Ontario, the destroyers Crescent, Micmac and Nootka, the frigate Charlottetown, the minesweepers Middlesex, New Liskeard, Wallaceburg and Revelstoke, the training ship Sans Peur, the auxiliaries Dundalk, Dundurn and Laymore, a stores carrier Eastmore, and a few smaller coastal vessels and tugs along with some ships listed in the reserve force in 1946-7. Canada, Department of National Defence, Annual Report, 1947 (Ottawa, 1948).

13 Joseph Jockel, No Boundaries Upstairs. Canada and the United States and the Origins of North American Air Defence, 1945-1958 (Vancouver, BC, 1987). 
escort groups for convoys and to form hunting groups to locate and destroy submarines, let alone defend Canada's long coasts. ${ }^{14}$

When the Soviet threat rose slightly during the first Berlin Crisis, ${ }^{15}$ Cabinet Defence Committee, on 26 October 1948, approved the procurement of three modern ocean-going anti-submarine warships, which became the St. Laurent destroyer escorts, along with four minesweepers, and three gate vessels. Even as this modest expansion got underway, refusals to carry out duties by members of the crews of three warships suggested all was not well in the navy. The "incidents" were short-lived - the crews returned to duty after the commanding officers heard the men's complaints about working conditions. A published report of the full investigation, led by Rear Admiral E.R. Mainguy, largely substantiated the men's complaints, observing that operational over-stretch or "making too many bricks with too little straw" was a causal factor. ${ }^{16}$ Importantly, the report recommended "a breathing space for essential training and the strengthening of its [the navy's] men and ships. ${ }^{17}$ However, alliance commitments put the RCN under pressure to keeps its few commissioned ships in intense operational cycles.

As Pearson had predicted, NATO maritime strategy was to "fight a war away from North America", but the alliance lacked sufficient naval and other resources to support that strategy. Instead NATO's 1949 strategic statement, MC 3, emphasized the American responsibility to deliver the atomic bomb promptly as a first priority. MC 3 also stressed the threat of the large Soviet forces stationed in Eastern Europe and called upon inadequate Western European forces to provide the "hard core of ground power" and tactical air defence to "arrest and counter ... enemy offensives". Finally, MC 3 assigned the United States and the

${ }^{14}$ LAC, RG 24, Accession 1983-84/167, box 455, file 1650-26, Vice Admiral H.E. Reid, CNS, to CINC, America and West Indies, Admiralty House, Bermuda, 8 January 1947.

${ }^{15}$ In 1948-1948, the Berlin Crisis created alarm in Washington. Canada refused to take part in the airlift in part because of "high handed actions by allies." Leigh E. Sarty, "The Limits of Internationalism: Canada and the Soviet Blockade of Berlin, 1948-1949," in J.L. Black and Norman Hillmer (eds.), Nearly Neighbours. Canada and the Soviet Union: from Cold War to Détente and Beyond (Kingston, ON, 1988). James Eayrs, In Defence of Canada, Growing Up Allied (Toronto, 1980), and Don Cook, Forging the Alliance: The Birth of the NATO Treaty and the Dramatic Transformation of U.S. Foreign Policy Between 1945 and 1950 (New York, 1989); Isabel Campbell, Unlikely Diplomats: The Canadian Brigade in Germany, 1951-1964 (Vancouver, BC, 2013), chapter 2.

16 Report on Certain "Incidents" which Occurred on Board HMC Ships Athabaskan. Crescent and Magnificent and on Other Matters Concerning the Royal Canadian Navy (Ottawa, 1949) [Mainguy Report], 33. .Richard Gimblett, "What the Mainguy Report Never Told Us. The "Tradition" of Mutiny in the Royal Canadian Navy before 1949" in Canadian Military History (Summer 2000), 85-92.

17 Ibid., 41. 
United Kingdom primary responsibility for securing and controlling the sea and air lines of communication. ${ }^{18}$ Given the weakness of European forces, American, British, and Canadian maritime support was crucial, but tellingly, Canada's commitment of ten percent of the defensive forces for the Atlantic sea lines of communication did not even rate a mention.

In private, American, British, and Canadian naval leaders disagreed about future maritime warfare. The Royal Navy $(\mathrm{RN})$ and the RCN shared lessons from the Battle of the Atlantic, emphasizing offensive and defensive anti-submarine warfare with lower priority for air defence, gunnery, and minesweeping capabilities. ${ }^{19}$ In contrast, the USN sought an expanded offensive role for carrier aviation, building upon experiences in the Pacific theatre during the Second World War. After a heated public debate in 1949, US Secretary of Defense Louis Johnson rejected the USN's proposal to build a new generation of super carriers capable of operating nuclear-armed aircraft and instead approved the air force's B-36 heavy bomber programme. ${ }^{20}$ Each service continued to promote its own interests, creating tensions in the alliance, high force goals, and a commitment-capability gap which grew over time. ${ }^{2}$

The Canadian Chiefs of Staff Committee protested the alliance's unrealistic force goals and the absence of any scales of attack for different regions, a result of an American refusal to forward such information to NATO ${ }^{22}$ Nonetheless, the RCN committed most of its warships to the North Atlantic, reserving only a few minesweepers for

18 Gregory W. Pedlow, NATO Strategy Documents, 1949-1969 (Brussels, 1997), 16-17. The United States Air Force had the prime responsibility for delivering the bomb.

19 G.C. Peden, Arms, Economic, and British Strategy (Cambridge, 2007), 241-244. Malcolm Llewllyn-Jones, The Royal Navy and Anti-Submarine Warfare, 1917-49 (New York, 2006). Llewllyn-Jones neatly demonstrates the holistic nature of RN thinking about tactical offensive and defensive anti-submarine measures.

20 Jeffrey G. Barlow, Revolt of the Admirals. The Fight for Naval Aviation, 1945-1950 (Washington, 1994) and From Hot War to Cold War. The U.S. Navy and National Security Affairs, 1945-1955 (Stanford, 2009), 180-183, 288.

${ }^{21}$ Eric J. Grove and Geoffrey Till, "Anglo-American Maritime Strategy 1945-1960” in John B. Hattendorf and Robert S. Jordan (eds.), Maritime Strategy and the Balance of Power. Britain and America in the Twentieth Century (New York,1989), 282-3; Joel Sokolosky, "Seapower in the nuclear age: NATO as a maritime alliance" ( PhD thesis, Harvard, 1986), 43. The North Atlantic Ocean Regional Planning Group which preceded the Supreme Allied Command Atlantic SACLANT suffered from this issue. Sokolosky notes that the American forces disagreed on Soviet submarine capabilities at this time. In 1950, the Air Warfare Division of American Navy Department believed that Soviet air power was a most serious threat in the Mediterranean and Eastern Atlantic.

${ }^{22}$ DHH, Raymont fonds, 73/1223, box 60, Special meeting, Strategic guidance - NAORPG, SG 13, 7 December 1949.The SG represented France, the United Kingdom, and the United States and provided strategic guidance, approving plans and force goals before the higher NATO committees examined them. The SG issued MC 3. 
the defence of Canada's West Coast. ${ }^{23}$ NATO's maritime strategy emphasized support to Europe, but the American, British, and Canadian disagreements plagued planning. The alliance also depended upon scanty resources, heightening the importance of existing warships and making it difficult to dispose of older, less effective ships. RCN leaders used the diplomatic requirement to reassure European allies as a tactic to defend vulnerable resources in inter-service skirmishes in lieu of operating fewer, better warships.

By March 1950, Canada's nascent naval aviation arm - with a large number of accidents and deaths, a miserable training record, and bad publicity - was under review. Rough weather in the North Atlantic frequently grounded RCN aircraft and the aircraft themselves had mechanical difficulties. Some months before, Time magazine reported that the RCN carrier on loan from Britain, HMCS Magnificent was antiquated, unable to operate modern aircraft, and inefficient. In fact she could handle modern piston aircraft, but not the new jet aircraft and the heavier, faster aircraft soon to be in service. The British had designed light fleet carriers during the Second World War as an intermediate step between expensive full-sized carriers and small escort carriers. Although the Canadian chief of the naval staff, Vice Admiral Harold Grant, defended Magnificent, he knew her limitations and was aware of other grim issues which plagued $\mathrm{RCN}$ aviation. ${ }^{24}$

In April 1949, Grant had tried without success to acquire a larger British Hermes class carrier, but had instead been offered an unimproved light fleet carrier of the same class as Magnificent while she modernized. ${ }^{25}$ Beggars could hardly be choosers. Eventually, the RCN negotiated for Bonaventure, a light fleet carrier of the same class as Magnificent, but with an angled deck and other innovations which improved her performance. Such improved light fleet carriers remained in service with the $\mathrm{RN}$ and other navies for several more decades. However, the key question at this moment of fiscal restraint before the outbreak of war in Korea was should the RCN have a carrier at all? Yet because Canada had just tabled its force goals with NATO, which included the carrier, the chief of the general staff, Lieutenant General Charles Foulkes reluctantly acknowledged that Canada could not disband

\footnotetext{
${ }^{23}$ DHH, 2002/17, Joint Staff fonds, file 100, North Atlantic Regional Planning Group, Storrs, DNPO to COSC, 7 November 1951.

${ }^{24}$ LAC, RG 24, 1983-84/167, box 351, Grant to Claxton, 21 October 1949.

25 TNA, ADM 1/24842, Admiralty, "Minutes of a Meeting with the Chief of Naval Staff, R.C.N. on Saturday, $23^{\text {rd }}$ April, 1949”.
} 
naval aviation without significant political consequences. ${ }^{26}$ Canada would not rock the NATO boat. NATO's maritime strategy and force goals had thus saved the carrier at a crucial moment. In the meantime, the RCN showcased Magnificent in NATO exercises.

As American naval historian Jeffrey Barlow has told us, the heightened sense of threat and expanded American defence budget during the Korean Conflict helped revive the USN's bid for super carriers, the first of which, the 60,000-ton USS Forrestal, commissioned in $1955 .{ }^{27}$ By contrast, the RCN, limited by budget constraints to the single light fleet carrier, concentrated upon building a modern destroyer fleet. After sending three updated Second World War destroyers, HMC Ships Sioux, Athabaskan, and Cayuga to Korea in July 1950, the government approved expansion of the St. Laurent destroyer escort programme to seven vessels, followed by seven more (which became the Restigouche class) in 1951-2, along with ten more minesweepers and gate vessels. The RCN also modernized its existing Tribal class destroyers with improved anti-aircraft and anti-submarine armament and refitted the Second World War frigates and minesweepers held in reserve, increasing the numbers allocated to NATO and enhancing deterrence. In the interim, the RCN included frigates and minesweepers with limited capability and training complements among the antisubmarine escorts earmarked for the alliance. ${ }^{28}$

By the time NATO finally appointed Admiral Lynde D. McCormick, the first Supreme Allied Commander Atlantic (SACLANT) in early $1952,{ }^{29}$ American maritime strategy highlighted support to Europe. The USN and the RCN drew upon the political importance of reassuring and supporting European nations to justify increasing naval

\footnotetext{
${ }^{26}$ DHH, 73/1223, box 60, Chiefs of Staff Committee Minutes, 6 March 1950.

27 Barlow, The Revolt of the Admirals, 286-288.

28 Canada, Dept. of National Defence, Report, 1951 (Ottawa, 1951), 46. Second World War River class frigates refitted as Prestonian class ocean escorts. Algerine minesweepers counted in NATO force goals as coastal escorts. LAC, Manuscript Group 32, B 5 (MG 32, B 5), Brooke Claxton Fonds, volume 94, NSS 2200-Accelerated Defence Programme File, Grant to Claxton, 2 August 1950, RG 2, Cabinet Conclusions, 19 July 1950. Marc Milner, Canada's Navy. The First Century (Toronto,1999), 201-212.

${ }_{29}$ Canada had not supported Churchill in his fight to have a separate British Command. DHH, Raymont Fonds, 73/1123, box 61, Chiefs of Staff Committee Minutes, 15 January 1951. American Admiral Fechteler lost the chance to serve in the SACLANT post due to British delays. New information on Canada's position with regard to the appointment of SACLANT will appear in the forthcoming volume 3 of the official history of the Royal Canadian Navy. See also: Sean M. Maloney, Securing Command of the Sea. NATO Naval Planning 1948-1954 (Annapolis, Maryland, 1995), 112-135; Eric J. Grove, Vanguard to Trident, 103.
} 
resources in inter-service battles. ${ }^{30}$ Despite combat in Korea, the large scale NATO exercises Mainbrace in 1952 and Mariner in 1953 shifted attention and resources to Europe, helping SACLANT co-ordinate plans with the Supreme Allied Commander Europe (SACEUR - responsible for European defence) while highlighting the relative importance of the European theatre.

\section{Table One}

\section{Canadian NATO force goals, 31 December 1952}

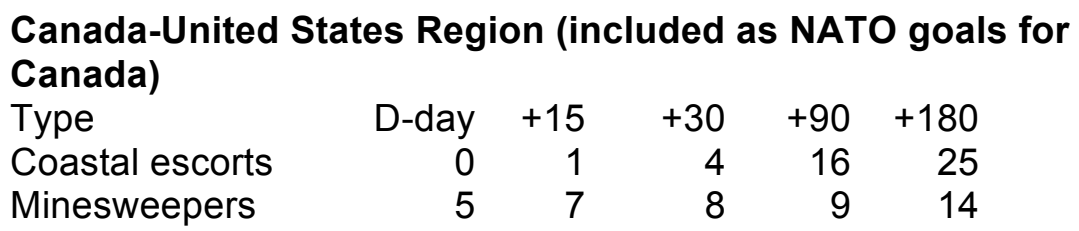

SACLANT
Light fleet carrier
Cruisers
Destroyers
Escorts

The Royal Canadian Air Force (RCAF) earmarked maritime aircraft for NATO as well. By 31 December 1952, there would be 12 maritime aircraft for $\mathrm{D}$-day building to 18 by $\mathrm{D}+180 .{ }^{31}$

Exercise Mainbrace in 1952 involved over 170 ships and numerous maritime aircraft from Belgium, Britain, Canada, Denmark, France, Norway, Portugal, the Netherlands, New Zealand, and the United States, covering a large ocean area, including the North Sea and the Baltic along the coasts of Norway and Denmark. ${ }^{32}$ The scenario was that

\footnotetext{
${ }^{30}$ Joel Sokolosky, "Seapower in the nuclear age," 66. Sokolosky concentrates mainly upon the American viewpoint here.

31 DHH, 2002/17, Joint Staff fonds, Box 23, File 137, Folder 4, From CCOS to CCJS(W), message. One cruiser was in reserve.

32 As Dean C. Allard observed, the USN had recognized the strategic significance of the Europe's northern flank during the First World War and had called for more aggressive action early on. He traces the importance of this area into the Cold War period and the USN's preference for a close in offensive against the sources of the enemy's maritime strength. Dean C. Allard, "Strategic Views of the US Navy and NATO on the Northern Flank, 1917-1991" in The Northern Mariner, 11:1 (Winter 2001), 11-24.
} 
the enemy had advanced to the Kiel Canal/Eider River and Narvik and Lofoten Islands after thirty days of fighting. ${ }^{33}$ Mainbrace forces reinforced NATO's northern flank, while maintaining the sea lines of communication in the face of submarine and long-range maritime patrol aircraft attacks. The exercise was particularly designed to promote carrier forces at the political and inter-service levels. Shortly after the exercise, the American Joint Chiefs of Staff approved SACLANT's offensive operations in support of SACEUR. SACLANT's 1952 defence plan called for the carrier striking force to employ atomic weapons and to undertake an attack at source mission as a primary role. The United States Air Force (USAF) had reluctantly agreed to carrier task forces for tactical land support in Denmark and Norway until later in the future war when the carrier forces might be able to attack Soviet submarines forced back to bases for fuel. ${ }^{34}$ General Matthew Ridgeway, SACEUR, declared the carrier forces on his northern flank "indispensable" to his mission. The exercise thus validated USN expenditures for powerful carrier forces at a key moment.

Mainbrace also justified the RCN's large warships. During the exercise, Magnificent acted as a carrier support force to a convoy proceeding from Scotland to Norway. Then her Avenger aircraft flew anti-submarine barrier patrols, while her Sea Furies supported amphibious landings on Jutland. Quebec, the cruiser, played a lone enemy raider and was deemed sunk. She then joined allied forces to take part in indirect bombardment of the Lofoten Islands. While Magnificent's Avengers scored a satisfying hit on an exercise submarine, poor weather had grounded carrier aircraft for much of the exercise and the RCN had been plagued by poor communications and a lack of training. ${ }^{35}$ However, Mainbrace's positive political impact proved more important than these performance deficiencies. Canada's permanent representative to NATO Council, A.D.P. Heeney, praised the Mainbrace concept, assessing its political product as "considerable" with "a spectacle of allied cooperation and unity... on [the] north east boundaries of NATO." Heeney informed

\footnotetext{
${ }^{33}$ Brassey's Annual 1953, 159-166, Crowsnest (October 1952).

34 U.S. Joint Chiefs of Staff, Records of the Joint Chiefs of Staff, part II, 1946-1953, Europe and NATO (Frederick, MD: University Publications of America, 1980), Reel 8, Joint Strategic Plans Committee, SACLANT emergency defence plan 1-52, 29 October 1952 and memoranda from Vandenberg to Joint Chiefs of Staff, 20 November 1952. Recall that MC 3 had European tactical air defence as its third task. The USAF agreement was on a temporary basis.

35 Crowsnest (December 1952); DHH, 81/520/8000, box 61, file 4, Captain K.L. Dyer to FOAC, in Reports of Proceedings, September 1952.
} 
Pearson, now secretary of state for external affairs, that Magnificent and the training cruiser Quebec gave "a good account of themselves". 36

The political situation in the Baltic was delicate. ${ }^{37}$ The Norwegians had nursed doubts about the alliance's reliance upon offensive air power, while a conservative group of Norwegian officers fought to keep national control over their own forces. ${ }^{38}$ During Mainbrace, the Soviet Red Star ran exaggerated accounts about wildly drunken Canadian sailors in Norwegian towns in an unsuccessful attempt to build negative propaganda. ${ }^{39}$ Canada's ambassador to Denmark, Minister E. D'Arcy McGreer commended Mainbrace which he believed had bolstered the anti-communist cause in Denmark, generally strengthening Danish resolve and improving public support for the alliance. Soviet-inspired attempts to create riots against the visiting troops in Denmark backfired badly. ${ }^{40}$ Denmark had abandoned a hundred years of non-alignment when it signed the North Atlantic Treaty and the Danish tradition of neutrality remained an important political consideration. The Soviets had also attempted to restrict foreign fleets in the Baltic and pressured the Danes against military integration into the western alliance. ${ }^{41}$ Overall, the alliance believed that Mainbrace bolstered alignment, demonstrating its political commitment to the northern flank as well as its determination and ability to operate its warships in the Baltic.

The RCN commitment of one light fleet carrier and a training cruiser showed political shrewdness, reinforcing the notion that these large warships directly supported the land battle in Europe and deterred Soviet attack in Central Europe. What mattered at the political level were public relations and the impact upon European politics, not tactical performance or actual capabilities. ${ }^{42}$ The strategy of offensive bombing

\footnotetext{
36 DHH, 2010/1, box 2, file 2, 1640-21-14, volume 1, A.D.P. Heeney to Secretary of State for External Affairs, 3 October 1952.

37 Jukka Rislakki "Without Mercy - U.S. Intelligence and Finland in the Cold War" in Journal of Military History, 79:1 (Jan. 2015), 128-148.

38 Kjell Inge Bjerga and Kjetil Skogrand, "Securing small-state interests" in ibid., 223-225. Norwegian concerns over command of their own forces resulted in extremely complex alliance command arrangements that took many years to achieve and were most unsatisfactory.

39 DHH, 2010/1, box 2, file 2, 1640-21-14, volume 1, The Red Star, 20 September 1952.

${ }^{40}$ Ibid., Minister E. D’Arcy McGreer, Report no. 478, 28 October 1952.

41 Jonathon Søborg Agger and Trine Engholm Michelsen, "How strong was the 'weakest link'? Danish security policy reconsidered." in War Plans and Alliances in the Cold War. Threat perceptions in the East and West, Vojtech Mastny, Sven G. Holtsmark, and Andreas Wenger(eds.) (London and New York, 2006), 240-243.

42 Crowsnest (December 1952); DHH, 81/520/8000, box 61, file 4, Captain K.L. Dyer to FOAC, in Reports of Proceedings, September 1952.
} 
provoked the Soviets: they objected to the NATO exercise on their maritime periphery, worrying that NATO forward bases might allow advance attacks on the Soviet Union and they accused the Danes of turning their country into a base for foreign troops. Under these circumstances, the Mainbrace decision to emphasize the future land war in Northern Europe rather than the offensive bombing aspects of SACLANT strategy was wise. ${ }^{43}$

However, the British objected to the very aspects of Mainbrace that the Americans and the Canadians had endorsed. The British Admiralty criticized American Admiral William M. Fechteler, the chief of naval operations, who "thinks of the Striking Fleet in Pacific terms...a major feature in the land campaign, a task force to support SACEUR on the Mainbrace model." The British admirals made scathing criticisms about the poor American anti-submarine performance and pointed to the striking fleet's vulnerability to submarine attack at the exercise's end. ${ }^{44}$ Britain's decline in international prestige heightened their resentment of superior American aircraft performances which were evident during NATO exercises. Not only did the RN draw upon their Second World War Atlantic expertise, they also hoped to acquire atomic weapons capable of penetrating submarine pens ${ }^{45}$ arguing that this contribution would give the British a voice in the American striking force deployment. ${ }^{46}$ Their disappointment over British decline and their longing for better British commands and for more influence gave their critiques a bitter edge.

Exercise Mariner held in September 1953, tested the command structure and employed the striking force in Northern waters, emphasizing air defence and the protection of shipping against simulated atomic attacks. Mariner was beset by terrible weather, impeding the striking force which had headed across the North Atlantic from North America to Europe and preventing planned carrier strikes and shore

43 DHH, 2010/1, box 2, file 2, 1640-21-14, volume 1, Ford, Charge d'Affairs, Moscow, to Secretary of State for External Affairs, 6 October 1953. (from declassified photocopies held at DHH); ibid., Minister E. D’Arcy McGreer, Report no. 478, 28 October 1952.

44 TNA, ADM 116/6438, FEH Hopkins, for DAOT, 11 March 1953.

45 Richard Moore, The Royal Navy and Nuclear Weapons (London, 2001), 98-102 The RN committed two carriers to NATO's Atlantic Striking Fleet, emphasizing its role as a "covering force... analogous to the Grand fleet of World War One and the Home Fleet of World War Two... the umbrella under which we exercise command of the sea". This offensive force for Atlantic and northern waters provided essential cover for defensive forces and attacking the sources of threats to the defensive forces.

46 Grove and Till, “Anglo-American Maritime Strategy 1945-1960,” 284-285. 
bombardments. Worse still, the Royal Air Force Bomber Command outraged naval leaders when it badly damaged the defensive forces. At the end of Mariner, SACLANT Commander Admiral McCormick went public and declared that there was "a grave shortage of escort vessels and maritime aircraft". ${ }^{47}$

The detailed American and Canadian analyses of Exercise Mariner remain classified, but declassified British sources condemned the weakness of American anti-submarine tactics and expressed doubts about the likely success of the striking force which they considered vulnerable. ${ }^{48}$ At the political level, the British pushed hard for control of the controversial and unresolved command area located near the Iberian Peninsula and for control of the striking fleet. However, the American government was not about to concede command or control to the British. According to Betty Carney Taussig, Admiral Robert B. Carney, chief of naval operations, considered that some aspects of McCormick's handling of the British had been naïve. Shortly after the exercise, Carney replaced McCormick with Admiral Jerauld Wright who was determined to hold firm on American command of the strike force. ${ }^{49}$

As it turned out, the British were not united in their opinions about operational weaknesses during Mariner. Vice Admiral J. HughesHallett, the Flag Officer Heavy Squadron, Home Fleet, who had commanded the British component of the striking fleet, had actually agreed with most of McCormick's conclusions. In his view, although area commanders during the Battle of the Atlantic had to keep close control of fleets and ships, the striking fleet was an exception. While the British component of the striking fleet had improved a great deal from Mainbrace, Hughes-Hallett and Rear Admiral Goodwin, the American task force commander, warned that a combined American/British striking force was dangerous. British warships could not operate with American aircraft until communications were standardized. Hughes-Hallett also

\footnotetext{
${ }^{47}$ Brassey's Naval Annual 1954, 285-8; NATO Archives, Brussels, www.nato.int/archives/1st5years/chapters/9/htm.

48 TNA, ADM 116/6438, Operational Research Branch, Bomber Command, Report No. 338. While Bomber Command had cooperated with the USN in producing this report, the Admiralty did not accept all the conclusions. For all partners, service interests often collided with other interests, creating conflict and complexity.

49 TNA, ADM 204/101, McGrigor to Hughes Hallett, 5 May 1954; NA, ADM 116/6327, Vice Admiral J.Hughes-Hallett, to Maritime Analysis Team, Commander in Chief, Portsmouth, 14 October 1953. Betty C. Taussig, A Warrior for Freedom (Manhattan, KS, 1995), 194-5. Carney's wartime experience had been in the Pacific theatre and he was critical of the British. After serving as SACLANT, McCormick accepted a demotion, serving in the rank of vice admiral as president of the Naval War College.
} 
observed that the destroyers had slowed the force down during heavy weather. Like McCormick, he stressed the need for battleships to deny Russian cruisers access to the Denmark Straits and the Bear Island Passage. Hughes-Hallett admitted the superiority of the USN fleet train system and bemoaned the small size and design of British aircraft carriers, wondering if the new British angled deck would allow high performance jet fighters to land on the heavily pitching decks so common in the North Atlantic. ${ }^{50}$

He raised a key question for Canada because the RCN was in the process of negotiating for an angled deck on a refitted light fleet carrier, Bonaventure, which would replace Magnificent. Bonaventure was a huge step ahead, although it had limited long term capability and would not operate jet fighter aircraft after 1962. As it turned out, Mariner demonstrated clearly the dangers inherent in naval aviation, particularly for landing in bad weather. Magnificent was assigned to anti-submarine and air defence of a logistical convoy attached to the striking force as it crossed the North Atlantic. Open Canadian sources recount a near disaster when fog rolled in preventing the landing of nearly forty-two Canadian Avenger and American anti-submarine aircraft until the very last minute on 23 September 1953. Fortunately, Magnificent and her group stayed near the eye of the storm as they progressed south of Iceland across the Atlantic and the group also fought off cruiser and submarine attacks. ${ }^{51}$ Despite these close calls, Mariner reinforced the utility of the light carrier.

In the meantime, HMC Ships Algonquin, Swansea, and La Hulloise earned British praise for tactical performance in convoy protection in the Eastern Atlantic later on during the exercise, practicing anti-submarine warfare under enemy air attack. Quebec played a difficult role, especially for a training ship. She joined the Striking Fleet in bad weather and then joined a circular formation to protect the main task force. The poor weather impeded re-fuelling. Moreover, British and American analysis concluded that the formation was vulnerable to atomic attack and considered it "unlikely to remain standard in future". 52 Three RCAF maritime squadrons of Lancaster aircraft also took part, like the $\mathrm{RCN}$, in "blue" or western forces.

50 TNA, ADM 116/6327, Vice Admiral J. Hughes-Hallett, to Maritime Analysis Team, Commander in Chief, Portsmouth, 14 October 1953.

51 Crowsnest (December 1953) and Stuart E. Soward, Hands to Flying Stations. A Recollective History of Canadian Naval Aviation, Volume One, 1945-1954 (Victoria, BC, 1993), 257-8.

${ }^{52}$ Crowsnest (December 1953) and Stuart E. Soward, Hands to Flying Station, 257-8. 
During the exercise, the RCN again touted its larger warships. Over twenty thousand people visited Magnificent and Quebec in New York City and over four hundred crew members donated blood to the American Red Cross just before the exercise got underway. The RCN newsletter publicized the American commander's messages praising the performance of the Canadian warships and headlining Mariner as "History's Greatest Maritime Manoeuvres". ${ }^{53}$ Surprisingly, in view of the weather, Magnificent's aircraft flew on fifteen out of nineteen days, making 257 sorties and her helicopter also made eighty-eight flights. The chief of the naval staff, Vice Admiral E.R. Mainguy, had already informed his government that the two cruisers, HMCS Ontario and HMCS Quebec, allocated to SACLANT as part of Canada's NATO contribution, were no longer effective fighting ships. ${ }^{54}$ And so, the operational and tactical challenges made little impact at the Canadian political level. Rather, Mariner provided another public relations triumph for Canadian naval aviation.

During the autumn of 1953, the Canadian government approved assignment of the Canadian carrier with five British escorts to an ocean area close to Brest, France to protect reinforcements and supplies for SACEUR in the early stages of a war. Canadian escorts would replace RN warships when available. These early SACLANT plans included three Canadian escorts in a mixed American-Canadian carrier group. Though Canada insisted upon national groups in principle, the interim war plans formed multi-national groups as ships became available, reflecting a growing NATO spirit. SACLANT planned for five carrier support groups, including the above-mentioned Canadian-British and American-Canadian mixed groups, one American and one British operating from Plymouth, England. A Netherlands group would operate from Belfast, but it would not be available until D plus 30 days. ${ }^{55}$

Despite the Admiralty's concerns about anti-submarine warfare and other less pressing qualms arising from American dominance of the alliance, the trend towards powerful nuclear weapons in lieu of conventional forces continued. ${ }^{56}$ During 1953, the Eisenhower

\footnotetext{
53 Crowsnest (September and December 1953).

54 DHH, 2002/17, NSTS 11640-26, Mainguy to Claxton, 31 August 1953. Some RCN officers still clung to the notion of big ship training and hoped to keep them for that purpose.

55 DHH, 73/1223, box 61, file 1307, Chiefs of Staff Committee Minutes, 543rd meeting, 15 September 1953; DHH, 73/1223, box 65, file 1327, Cabinet Defence Committee, $95^{\text {th }}$ meeting, 6 October 1953.

${ }^{56}$ NATO had approved unrealistically high force goals in Lisbon in 1952 and never came close to fulfilling them.
} 
administration stressed long term nuclear deterrence, easing the pressure to meet unrealistic short term force goals. ${ }^{57}$ SACLANT's 1954 emergency defence plan confidently highlighted the striking fleet's role in "attacks on ports, ships in harbour, naval and air bases ... with primary

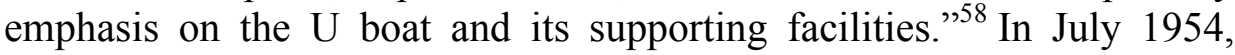
Admiral L.J. Huffman, USN, presented the SACLANT 1957 capabilities plan to the allies in Washington, admitting the inadequacy of defensive resources for convoy support. SACLANT's offensive capabilities for attacking submarine bases and supporting operations off Norway were stronger and SACLANT planners hoped that RAF Bomber Command would build better capacity for a mining campaign to close the Baltic. ${ }^{59}$

In December 1954, with NATO adoption of MC 48, matters came to a head. Putting aside their many differences, Admiral Wright, SACLANT, and two British admirals, McGrigor ${ }^{60}$ and Creasy ${ }^{61}$ spoke out against the new strategy. Mostly they objected to its concentration upon the first phase of a future war. SACLANT plans already incorporated an all-out nuclear attack, but none of NATO's top maritime commanders accepted the notion of two phases and the implication that the second phase hardly counted. They insisted that command of the sea must be maintained from the outset of the war and throughout. ${ }^{62}$ Their protests landed on deaf political ears - partly because few believed war was likely. ${ }^{63}$ Canada's General Foulkes merely commented that MC 48 was a political strategy - intended to encourage governments to provide maximum resources for the initial phase of a conflict - and like others, he dismissed their operational arguments.

In the meantime RCN officers were becoming increasingly critical of SACLANT operational plans. Captain D.G. King, the

\footnotetext{
57 Jeffrey Barlow, Hot War to Cold War, chapter 18, footnote 96.

58 Moore, The Royal Navy and Nuclear Weapons, 98-99, reference to PRO, ADM 205/94, EDP$1-54$, annex C.

59 DHH, 2002/17, file 114, Air Commodore H.H.C. Routledge, Co-ordinator Joint Staff, to CCOS, Report on SACEUR and SACLANT capabilities study, 15 July 1954.

${ }^{60}$ Ibid. Sir Rhoderick McGrigor was first sea lord and chief of the naval staff.

61 Sir George Creasy held the commander-in-chief channel command (CINCHAN) - a NATO command from 1954 to 1957 . He was the commander-in-chief eastern Atlantic (CINCEASTLANT ) - a NATO sub-command under SACLANT before this.

62 DHH 2002/17, file 88, Memo from Rear Admiral De Wolf, Chair, CJS W, to CNS, 1 February 1955.

${ }^{63}$ Soviet leader Nikita Khrushchev implemented reforms in the Soviet Union, lowering international tension. He also opposed a Soviet carrier force, supporting the development of submarines instead. Aleksandr Fursenko, Timothy Naftali, Khrushchev's Cold War: The Inside Story of an American Adversary (New York, 2007).
} 
Canadian director of naval operations and plans considered SACLANT too optimistic about the ability of the striking forces to deliver nuclear weapons because of the vulnerability of striking forces. He and others doubted the ability of carrier borne and maritime patrol aircraft to detect submarines and the capability of the surface ships to destroy them. ${ }^{64}$ King's criticisms hinted at widespread dissatisfaction with NATO's maritime strategy and with the lack of conventional anti-submarine warfare capability demonstrated during Mainbrace and Mariner. Soon RCN officers questioned Canada's commitment of naval resources to the land war in Europe in the early phase of a future war. ${ }^{65}$ By early 1956, Canadian naval leaders, examining the new threat of missile launching submarines to North America, initiated a new national maritime strategy independently of their allies. ${ }^{66}$

The RCN naval warfare study group visualized a two phase war. They emphasized phase one of an all-out atomic war and separated it completely from phase two or the long "broken- backed" war which might drag on with survivors utilizing the few effective military resources remaining in the aftermath of the intense nuclear exchanges of the first phase. The study group assumed that during phase one all Canadian maritime forces would remain under national command, concentrated in waters off the Canadian coasts to locate and destroy submarines. ${ }^{67}$ Foreshadowing later NATO and SACLANT policies, all shipping was to clear the high seas and main ports as soon as possible after the outbreak of war and then shelter in minor harbours. Anti-

64 DHH, 2002/17, file 115, Captain D.G. King, DNPO- to ACNS(P), capabilities studies of SACLANT 2 November 1954.

65 DHH, 73/1223, Raymont Fonds, box 61, file 1307, Cabinet Defence Committee, Minutes, 6 October 1953. The Canadian Cabinet Defence Committee had approved SACLANT plans assigning Canadian warships to the Eastern Atlantic on the understanding that he would re-assign the warships if the threat changed, especially with regard to the Canadian sub-area located in the Western Atlantic.

${ }^{66}$ RCN officers suspected that the USN might have similar ideas. They presented USN Vice Admiral M.B. Gardner, deputy chief of naval operations (plans and policy) with an outline of their developed plans at a Naval Board meeting on 18 May 1956. DHH, 81/520/1000, Naval Board minutes, 18 May 1956.

${ }^{67}$ Campbell, "A transformation in thinking: The RCN's naval warfare study group of 1956." The Naval Warfare study group concluded that the submarine must snort before reaching positions about 200 miles from likely targets; they therefore established three zones of defence. The first zone, a denial zone, included 200 miles of sea from the coastline. The second zone, an inner combat zone, encompassed the area of underwater surveillance, and the area where they expected the majority of anti-submarine forces to be concentrated. The third zone, the outer combat zone, extended another 100 miles, and included early warning systems and tactics to force enemy submarines to traverse barriers, or submerged forces with detection and attack capabilities. The RCN transmitted its idea to the USN only after it reported to the CNS on these ideas. 
submarine forces would not be available to protect shipping until the long "broken- backed" phase. If no one was quite certain what resources might survive to that stage, the group nonetheless had a clear idea of the priorities appropriate to each phase. The Canadians appreciated that SACLANT forward barriers, such as the Northern Chain and surveillance from Greenland to Norway, via Iceland and the Faroe Islands, might provide strategic warning, but assessed that some Soviet submarines would reach North American coastlines undetected. ${ }^{68}$ The RCN would focus upon detecting and eliminating the Soviet submarines which penetrated the NATO barrier forces.

SACLANT's 1956 emergency plans did not address the new threat of missile launching submarines to North America nor did they separate the two phases of war. ${ }^{69}$ The RCN sent a brief to its representative at the NATO multilateral discussions in Paris in February 1956, criticizing the assignment of RCN forces to the EASTLANT areas in the early days of a future war and recommending that the RCN support re-supply to Europe as a phase two function. RCN staff also did not agree with leaving the West Coast of Canada "virtually undefended." Up to this point, they quietly discussed their ideas at the operational level rather than in the political arena, avoiding tension with the European partners. ${ }^{70}$ However by 1957, with RCAF and government approval, Canadian officials pushed their own new maritime strategy declaring that they were "re-assessing requirements for the defence of Canadian offshore waters in relation to the need to support a "forward defence' concept" in the annual review forum which all NATO allies attended. ${ }^{71}$ The RCN then requested that SACLANT reassign RCN forces to North American waters during phase one to deal with missile launching submarines. ${ }^{72}$

In reply, the SACLANT team stressed its forward defence concept - emphasizing the need to bottle up Soviet forces in the Baltic. Shortly after, because of German-Danish disagreement, the RCN was

${ }^{68}$ DHH, 74/723, Declassified, RCN/RCAF Concept of Maritime Operations, 2 April 1957. Some submarines might escape detection, while others might approach the Pacific coast.

${ }^{69}$ The Soviets launched their first ballistic missile from a submarine in 1955. Soon after, the Soviet fishing fleet began activities off the coast of Newfoundland in international waters close to the North American continent, possibly masking the presence of submarines. By the time of the Cuban Crisis, Soviet diesel-powered nuclear armed submarines posed an operational threat to North American waters.

${ }^{70}$ LAC, RG 24, box 21210, NSTS 11640-1 (declassified notes), Brief for RCN representative, 2 February 1956.

71 DHH, 2002/17, file 141, Canadian reply to Annual Review Questionnaire, 1958, 29 August 1957.

${ }^{72}$ DHH, 2002/17, file 115, Capt. J.A. Charles to ACNS (P) and CNS, "Comments on points to raise with SACLANT" 27 February 1958. 
offered a command position in the Baltic which it did not accept. Undoubtedly the Baltic was an important NATO maritime priority, but despite the obvious prestige of this offer, the RCN remained focused upon national defence and the future threat of guided and ballistic missiles widened the wedge between European and North American interests in the alliance. ${ }^{73}$

In May 1957, NATO adopted MC 14/2, a revised strategic concept to build upon the common notion of deterrence. It emphasized the role of nuclear weapons but with capabilities for an early flexible response. ${ }^{74}$ SACLANT's staff produced MC 70, The Minimum Forces Study, 1958-1962 designed to implement MC 14/2, but unlike SACEUR's MC 70 study, SACLANT's did not contain the planned deployment of forces and disappointed Canadians. The Canadian Joint Planning Committee did not agree with the SACLANT assessment that if the first phase ended in a stalemate that "NATO naval forces, still organized and relatively intact, with mobility, atomic fire power, and capable of sustained combat operations at sea,... might well prove decisive." ${ }^{75}$ They also disagreed that "probably naval forces... will provide the best, if not the only, means of establishing and maintaining contact with a beaten, exhausted and disorganized enemy." ${ }^{, 76}$ Canada refused to support these statements and asked to see SACLANT's specific intended deployments.

Canada also rejected the MC 70 recommendation for provision of a Canadian helicopter carrier. Within the RCN, naval aviators such as Captain A.B.F. Fraser-Harris who served on SACLANT's staff during this period and Commander "Jim" Hunter who had been part of the Naval Warfare study group, promoted the idea of a helicopter carrier. ${ }^{77}$ However, lacking government approval for the second carrier, the RCN

\footnotetext{
73 Eisenhower Centre, Norstad Papers, box 47, Norstad to MOD Canada, 13 June 1958. This complex topic could form its own separate paper, but from the view of the RCN, the lack of a sufficient number of experienced qualified high ranking officers precluded agreement. Note that the Canadian government was seeking higher ranking Army appointments in SACEUR at this time.

${ }_{74}$ Pedlow, NATO Strategy Documents, 277-313.

$75 \mathrm{DHH}, 2002 / 17$, file 4 , as paragraph 20 of the MC 70 study suggested.

76 DHH, formerly 193.009 (d53) now under 2002/17, box 71, file 4 Special Chiefs of Staff Committee meeting, 9 November 1957, including JPC comments on SACLANT minimum force study, 1958-1962. Note a comparison of the RCN/RCAF concept and the MC 14/2 reveals very different documents, serving completely different purposes, using very different language and, if conceptually similar, in no sense carbon copies.

77 Michael J. Whitby "Commodore A.B. F. Fraser-Harris and the Royal Canadian Navy" in The Northern Mariner, 22:1 (January 2012) 9-10, 13-14; Isabel Campbell, "A transformation in thinking: The RCN's naval warfare study group of 1956 ".
} 
focused successfully upon the operation of helicopters from escorts, and worked closely with the USN to address other concerns with respect to phase one and the defence of North America. By March 1958, the American-Canadian bilateral plans reflected the new threat of missilefiring submarines and RCN staff asked SACLANT to address the threat, using resources like the SOSUS underwater surveillance system that were not yet shared among the NATO partners. They recommended that "the first phase of war visualize the increased use of missile-carrying submarines [with] improved means of submarine detection" as a priority. They also insisted that "naval forces, like shield forces, must be in commission, trained, ready and on station before hostilities commence." ${ }^{, 78}$ Stressing the need for peacetime surveillance of submarine operations, the RCN considered deploying forces before the outbreak of war under the Canada-United States Regional Planning Group as a compromise. Finally, they objected to SACLANT plans for the early institution of a convoy system as "not in accord with the concept in MC 70," advocating instead to clear the ocean in the early days of all-out war as later became part of NATO's plans. ${ }^{79}$

Despite the criticisms of NATO, the RCN drew upon MC 70 and SACLANT plans at the political level to justify a request for large tanker-supply ships. In 1958 the Canadian government approved the construction of a new tanker-supply ship to provide mobile logistical support for the fleet. ${ }^{80}$ Perhaps hoping for the support of new Prime Minister John Diefenbaker, an enthusiastic supporter of closer relations with Britain and Europe, the RCN referred to the commitment of the warships to the Eastern Atlantic at D day plus 30 days - or during the long "broken-backed" war - to rationalize this new expenditure. ${ }^{81} \mathrm{RCN}$ staff argued that operating the Tracker anti-submarine and Banshee fighter aircraft near Brest, France as planned during the long" brokenbacked" war would require substantial spares, parts, fuel, and other

\footnotetext{
78 DHH, 2002/17, file 15. My emphasis. This last point reflects another unique RCN concept of operations named the "beartrap concept of operations" (different from the helicopter pull-down device of the same name). This concept called for positioning of warships at specific locations identified as likely spots for missile-launching submarines to appear. The concept encountered severe criticism in Ottawa, but Admiral Wright, as SACLANT in 1960, expressed interest in it.

79 DHH, 2002/17, file 117, Report of discussions with SACLANT, held 3 March 1958.

${ }^{80}$ Cabinet Committee approved the construction of Provider on 12 November 1958. Later on, Canada approved two more which became Preserver and Protecteur.

81 DHH, 73/1223, box 65, Cabinet Defence Committee minutes 12 December 1958;DHH, 2002/17, box 81, file 12, Chiefs of Staff Committee minutes, 10 June 1958. NATO's MC 55 stressed the need for logistical support for ninety days of war.
} 
support. ${ }^{82}$ More important, new RCN tanker supply ships would provide greater independence and better flexibility to respond to a host of different operational requirements than the $\mathrm{RCN}$ had had with the coastal tankers it previously relied upon.

The RCN agreed to meet the MC 70 requirement for twenty-nine escorts by 1963, but deployed one third of them in peacetime to the West Coast of Canada in $1958 .{ }^{83}$ So while Canada did not withdraw warships from SACLANT, in practical terms one third would not be available in the Atlantic until after the first phase of a future war. The USN took a more direct approach and unilaterally re-assigned many of its oceangoing escorts to the Canada United States Regional Planning Group in 1958. SACLANT claimed that the submarine launched missile threat to North America was his responsibility in the hope of retaining these warships under his NATO command. However, his command had only partially addressed the issue ${ }^{84}$ Faced with American and Canadian tactics in late 1958, SACLANT created a new command, Commander North American Anti-Submarine Defence Force Atlantic task group (CTG) 217) responsible for integrated anti-submarine activities against Soviet submarines attempting to launch missiles against North America. ${ }^{85}$ This new organization foreshadowed the direction of RCN and USN thinking in the coming years.

CTG 217 included a new Canadian sub command, CTG 217.1, allowing the RCN to retain operational control of Canadian warships and maritime aircraft. The navy's close-in defence plan resembled the earlier Canadian concepts, but extended the area of defence out to five hundred miles from the previous three hundred to allow for the estimate range of submarine-launched missiles. ${ }^{86}$ At first, the RCN committed one carrier

82 DHH, 2002/17, file 117, Capt. Charles, DNPO "Comments on CINCEASTLANT EDP 1-58," 17 July 1958.

83 DHH, 2002/17, file 142, "NATO Annual Review, Examination of Canada," 5 November 1958.

84 DHH, 2002/17, file 143, Capt. J. A. Charles, DNPO, "Memo on ARQ 58, Annual Review of the US" to ACNS (A \& W), VCNS, CNS, 6 November 1958; DHH, file 117, "Changes to CINCWESLANT - emphasis phase one and reduction of forces in phase 2, 17 July 1958." SACLANT reduced assignment to EASTLANT by two UK carriers, two US carriers, and eighteen UK maritime patrol aircraft, while increasing the destroyer assignment by eight UK destroyers and two Canadian destroyers. The carriers to EASTLANT by D +30 were now one Canadian and one Netherlands. Ibid., Capt. Charles, DNOP, "Change 3 to WESTLANT planning guidance," 31 July 1958.

85 DHH, 2002/17, file 118, Capt. Charles, DNPO "Comments on COMNODEFLANT EDP 58" to to ACNS (A \& W), VCNS, CNS 10 October 1958 (originally named Commander North Defence Force Atlantic or COMNODEFLANT but renamed in 1959 to COMNORASDEFLANT or Commander North American Anti-Submarine Force Atlantic as above)

${ }^{86}$ Ibid. 
and twenty-nine escorts to SACLANT on D-day, but sixteen escorts would remain with CTG 217.1 until D+60 days. ${ }^{87}$ By 1959, SACLANT's emergency plan reflected the changing threat posed by nuclear powered submarines, their increased patrol range, and their capability of limited operations under the polar ice cap. ${ }^{88}$ The following year, SACLANT gave greater priority to the striking fleet for offensive operations against missile armed submarines. The RCN carrier group would operate under CTG 217.1, the Canadian command at Halifax, until D+16 days when it would accompany a special convoy to the Eastern Atlantic and then operate out of Milford Haven or Brest. ${ }^{89}$ As the RCN had proposed, Canadian maritime aircraft took part in barrier exercises in the Western Atlantic during peacetime - valuable practice as it turned out for operations during the Cuban Missile Crisis. Conventional maritime forces thus played an integral role in deterrence, even if nuclear forces dominated the era.

By 1962, the American Polaris missile launching nuclear submarine had dramatically altered the strategic picture. As one USN officer explained to NATO Council, it was "able to operate with complete concealment in remote sea areas for launching a nuclear offensive in close proximity to targets". ${ }^{90}$ The USN hoped to have nineteen Polaris submarines in service by the end of 1964, providing an instrumental second strike capability. When President John F. Kennedy decided to support Britain's Polaris submarine programme in late 1962, the Americans trumpeted the value of this force to NATO, but the British Admiralty resisted measures to commit these British Polaris submarines to any multilateral NATO force, antagonizing the French who had already decided to build their own nuclear weapons systems. ${ }^{91}$ More broadly, the European allies doubted that the Americans and the British would use the Polaris and other independent nuclear forces to protect European interests.

87 DHH, 2002/17, file 118, DeWolf to CCOS, 9 October, 1958. By 1963, Canada fulfilled the SACLANT commitment of one carrier and twenty-nine escorts. It committed fourteen escorts and ten minesweepers to the Canada-United States Regional Planning Group. Canada, Special Committee of Defence, Proceedings, 9 July 1963. Testimony of Vice Admiral H.S. Rayner.

${ }^{88}$ DHH, 2002/17, file 118 DeWolf to CCOS, "SACLANT EDP 1-59."

89 DHH, 2002/17, file 118, Capt. Charles "SACLANT's EDP 1-60" to ACNS (P), VCNS and CNS; DHH, 2002/17, file 157, Summary appraisal by Secretary General, NATO Annual Review 1963, volume 2, 1640-24-63 C-M (63) 96, 29 November 1963.

${ }^{90}$ DHH, 2002/17, file 118, J.K. Starnes, Dept. of External Affairs, "Report on NATO Ministerial Meeting 24 December 1959 and Extract from verbatim record of meeting of North Atlantic Council," 16 December 1959.

91 Andrew John Priest, "Two Among Many. Anglo-American relations, multilaterals and naval policy, 1962-1968" (Doctoral Thesis, University of Birmingham, 2002). 
From the Canadian perspective, the Soviet fishing fleet with over five hundred and fifty trawlers off the coast of Newfoundland by 1962 presented special and troubling challenges. The fishing fleet might impede submarine detection, while providing support to Soviet submarines and so it seemed essential for Canadian warships to monitor and to investigate these vessels.

\section{Table Two}

Canadian NATO force goals, 9 July 1963

On the Pacific coast

(14 escorts counted for CUSPRG NATO force goals)

Type

Destroyers 7

Coastal escorts 7

Minesweepers

Submarines

Maintenance Repair ship

1 (American on loan)

1

\section{On the Atlantic Coast}

(1 carrier and 29 escorts for SACLANT.

6 Minesweepers counted as CUSPRG NATO force goals)

Light fleet carrier

Destroyers

Frigates

Minesweepers

6

Submarines

Fleet replenishment ship

Maintenance repair ship

3 (British on loan)

1

1

As well as RCAF earmarked three maritime patrol squadrons on the Atlantic Coast for SACLANT and one on the Pacific Coast for which remained under national control in wartime. ${ }^{92}$

92 Special Committee of Defence, Proceedings, 9 July 1963. Testimony of Rear Admiral H.S. Rayner16 July 1963, Testimony of Air Marshal C.R. Dunlap. (Ottawa: Queen's Printer, 1963) 
Yet, whatever criticisms Canadian naval officers had of alliance strategy and plans, they considered that integrated anti-submarine forces were absolutely essential to deterring the Soviet missile-launching submarine threat in the greater Atlantic. ${ }^{93}$ During the early 1960 s, the RCN justified its case for anti-submarine surface vessels by referring to possible conventional warfare in Europe and hence the need to protect the Atlantic shipping that would sustain the forces in Europe against Soviet submarines conducting conventional anti-shipping warfare. This emphasis on conventional warfare anticipated NATO's shift to flexible response. In 1963 the RCN met the agreed SACLANT requirements with its expansion to 21,469 personnel, the peak strength for this Canadian service in peacetime. ${ }^{94}$

SACLANT and SACEUR experienced continued command and control issues, especially in European waters. By December 1963, the NATO naval commander recommended extending the SACLANT area in the Atlantic southwards and amalgamating parts of two British commands - the sea areas of the Channel command - with that of the Eastern Commander Atlantic who operated under SACLANT. SACEUR had not yet resolved the problems surrounding the Mediterranean command. His staff developed seven principles, including the need for fewer and simpler commands, avoiding the rotation of senior commanders amongst nationalities, and keeping anti-submarine warfare and control of shipping under a single centralized command. However political factors, the pressing complication of French naval forces, and other national interests impeded progress on these matters. ${ }^{95}$ French General Charles Ailleret eloquently expressed his government's opposition to the American push for flexible response, a strategy of escalating steps including conventional response, to deter Soviet attack. NATO would have to give up too much ground and "too much flexibility" was contrary to deterrence and might invite limited aggression. While France committed forces to her allies in an emergency, no French signature would go on any document promoting flexible response. ${ }^{96}$

93 Canada, House of Commons, Parliamentary Special Committee on Defence, Minutes of Proceedings and Evidence, 9 July 1963 (Ottawa,1963), 88, 116.

94 Ibid., 109, 120.

95 DHH, 73/1223, box 221, file 1810, Military Committee minutes, 13 December 1963 (open portion).

${ }^{96}$ Ibid. 
After Charles De Gaulle withdrew French forces from NATO commands, NATO approved flexible response with MC 14/3 in 1967. ${ }^{97}$ MC 14/3 called for a "secure retaliatory strike capability" which Polaris provided. It also called for "forces in being" to deal with limited or local aggression. To fulfill this requirement, NATO maritime members, including the RCN, contributed warships to the Standing Naval Force Atlantic which was formed in early 1968. Comprised of standing contributions of four to six destroyers and frigates, this force helped to reassure European allies of a rapid alliance response without recourse to nuclear weapons. Although the British and the French developed their own nuclear powered submarines at great cost, the other NATO allies, like Canada, could not afford the technology. Instead the RCN had acquired three Oberon class submarines, excellent investments providing anti-submarine capability in the coming decades. SACLANT accepted these ocean-going warships as replacements for surface vessels in Canadian force goals on a one-to-one basis. ${ }^{98}$ A new Liberal government under Lester B. Pearson then cut budgets, cancelled the Conservative government's planned general purpose frigates and retired older frigates. ${ }^{99}$ Later, it approved the construction of four large helicopter destroyers allowing Canada to focus on fewer and more capable warships -though at a much higher cost than forecast. ${ }^{100}$

When Prime Minister Pierre Trudeau came to power in June 1968, national interests came to fore and Canada cut the strength of its brigade group and air division located in Europe by half, sending political shock waves across the NATO forum. Bonaventure, which had just undergone a costly refit, was decommissioned, and the 1971 White Paper placed less emphasis upon anti-submarine warfare. In 1969, Canadian defence strategist George Lindsey had argued that even if Canada and other NATO countries relied upon the American nuclear deterrent, Canada exercised sovereignty by protecting its own coastlines. ${ }^{101}$ Canada's forces had taken this stand from the beginning -

\footnotetext{
${ }^{97}$ Pedlow, NATO Strategy Documents, 347-370.

98 Little is known of their operations, but see Michael Whitby, "Boomers, Boomers, Draggers and Black Boxes: The Operational Legacy of Canada's Oberon Class Submarines, 1983-1998" in The Northern Mariner, 23:3\&4 (2013), 367-398.

99 Pearson's government implemented unification of the Canadian forces in February 1968 and the RCN disappeared as Maritime Command took over many of its former functions. The government also accepted American nuclear weapons for the RCAF and the Canadian Army.

100 And as Marc Milner points out, much of the original General Purpose Frigate capability survived in the Iroquois Class. Milner, Canada's Navy, 266.

${ }^{101}$ DHH, 87/253-II-20.9, George Lindsay fonds, "Sub-committee on maritime forces; Sub Com[mittee] of Standing Com[ission] on External Affairs and Nat[ional] Def[ence] - [1969] -
} 
the naval warfare study group had contributed valuable concepts, influencing NATO's maritime strategy, and shifting the distribution of maritime resources to the defence of North America. Now the Trudeau reassessment put greater stress upon surveillance and defence in the Arctic. Still, Canadian forces continued to exercise with SACLANT. The Standing Naval Force Atlantic provided practical peacetime operational experience, including command of the multinational force which was rotated among the countries supplying warships. The force served public relations and solidarity purposes just as the early 1950s exercises had with Exercise Artic Ice in 1970, taking place off the coast of Norway, followed by additional exercises there and in Baltic waters. ${ }^{102}$

While the nuclear weapons eclipsed developments in conventional anti-submarine and mine warfare, small forces like the $\mathrm{RCN}$ remained relevant, contributing to deterrence and alliance solidarity even when their capabilities and performance were wanting. National and service interests could not be ignored, especially at the political level; the example of France underscores the difficulty of maintaining alliance cohesion in the face of diverging perceptions. In contrast, the RCN's ability to create independent plans and then to negotiate for a new Canadian sub-area command stands as a little known instance of the successful interplay between national and service interests in the formulation of NATO's maritime strategy. Yet, the Trudeau reassessment forced Canada's maritime forces to again re-assess their priorities and to justify weapons systems based upon national priorities rather than to rely upon alliance goals.

Canadian maritime strategy: should the emphasis be changed?", second draft by G.R. Lindsey," March 1969, Unclassified.

${ }^{102}$ Michael Young, "STANAVFORLANT in 1970: The First Canadian Command" in Canadian Naval Review Vol. 1, No. 3 (Fall 2005), 14-19. 